Article

\title{
Screening, Purification and Characterization of Anionic Antimicrobial Proteins from Foeniculum Vulgare
}

\author{
Raid Al Akeel ${ }^{1}$, Ayesha Mateen ${ }^{1}$, Rabbani Syed ${ }^{1, *}$, Abdullah A. Alyousef ${ }^{1}$ and \\ Mohammed Rafi Shaik ${ }^{2, *}$ \\ 1 Department of Clinical Laboratory Sciences, College of Applied Medical Sciences, King Saud University, \\ Riyadh 11451, Saudi Arabia; raalakeel@ksu.edu.sa (R.A.A.); ayeshamateen@gmail.com (A.M.); \\ abalyousef@ksu.edu.sa (A.A.A.) \\ 2 Department of Chemistry, College of Science, King Saud University, P.O. Box 2455, \\ Riyadh 11451, Saudi Arabia \\ * Correspondence: rabbanisyd@gmail.com (R.S.); rafiskm@gmail.com (M.R.S.); Tel.: +966-11-4693145 (R.S.); \\ +966-11-4670439 (M.R.S.)
}

Academic Editors: Paula A. C. Gomes and Stefania Galdiero

Received: 2 March 2017; Accepted: 6 April 2017; Published: 8 April 2017

\begin{abstract}
Foeniculum vulgare Mill., commonly called fennel, is a medicinal plant belonging to the Umbelliferae (Apiaceae) family, and is used in traditional medicine. Antibacterial peptides were isolated using sodium phosphate citrate buffer and, for extraction, cetyltrimethyl ammonium bromide (CTAB) buffer with $\mathrm{pH}$, have been employed and antimicrobial activity tested against four reference strains. The extracted protein was subjected to $3 \mathrm{kDa}$ dialysis and separation was carried out by DEAE-ion exchange chromatography and further proteins were identified by 2D gel electrophoresis. The results of Foeniculum vulgare elutes obtained from DEAE-ion exchange chromatography were tested for antibacterial activity. Elute 3 shows the highest antibacterial activity on Pseudomonas aeruginosa with a diameter of a zone of inhibition of $16 \mathrm{~mm}$ and $\mathrm{IC}_{50}$ value $25.02(\mathrm{mcg} / \mathrm{mL})$. Based on the findings of the wide usage in treatment of various ailments and day-to-day life, Foeniculum vulgare seeds were used in the present research and have shown promising antibacterial effects, which requires further proteomic research to authenticate the role of the anticipated proteins.
\end{abstract}

Keywords: Foeniculum vulgare; ion exchange chromatography; antimicrobial proteins

\section{Introduction}

Voluminous plants and plant extracts have a wide variety of resistance mechanisms to chemical, physical, and biological strains, like heavy metals, cold, drought, pathogens and contaminant attacks from bacteria, fungi, and viruses. Several plants exhibited complete genes, allied together for assimilated control over the infections from numerous types of pathogens [1]. Typically, the resistance control is accomplished by the discharge of secondary metabolites, such as phytoalexins, polyphenolics, and tannins, and the generation of pathogenesis-related proteins. In the early 1970s pathogenesis-associated proteins were primarily revealed from the leaves of tobacco. In response to the infections of tobacco mosaic virus were later well-defined as the induced proteins that are discharged through the pathogenic attacks [2].

Antimicrobial peptides are pervasive and the established host resistances, in contrast to pathogens and pests in different organisms, vary from microorganisms to animals [3]. Antimicrobial peptides occur in various molecular arrangements, while most of them are linear peptides from plants, insects, 
and animals. However, the bacteria harvest polycyclic peptides, for instance, lantibiotics, and complete principal forms of life harvest round peptides, which comprise bacteriocins from bacteria, theta-defensins from animals, and cyclotides from plants [4-6]. The preponderance of antimicrobial peptides from plants are Cys-rich [7]. Generally, numerous mutual features of plant antimicrobial peptides share with those from insects, microorganisms, and animals. They comprise characteristics, like their molecular arrangements. These features are well-signified by two plant antimicrobial peptide families, thionins and plant defensins. For example, knottin-type peptides inhibit enzymes, such as, proteases; hevein-like peptides bind chitins; and lipid transference proteins bind lipids to interrupt microbial permeation into cell membranes.

Foeniculum vulgare Mill., commonly called fennel, is a therapeutic plant belonging to the Umbelliferae (Apiaceae) family, is widely used in traditional medicine. This is one the most important plants, which has several pharmacological properties, both in vivo and in vitro, including anti-microbial, anti-viral, anti-inflammatory, anti-mutagenic activities, etc. [8]. Based on scientific evaluation and its use in traditional medicine, Foeniculum vulgare emerged as a good source of medicinal products for research, proving noteworthy in the field of pharmaceutical biology, as well as in the research and development for new drugs. Previous study showed that extract from Foeniculum vulgare has significant anti-bacterial activity against some tested foodborne pathogens [9]. There are many such authenticated studies where authors tested different parts of this plant, with promising results. Plant seeds possess antimicrobial proteins [10,11], defensins [12,13], thionins [14], lipid transfer proteins $[15,16], 2 \mathrm{~S}$ albumins [17,18], and ribosome-inactivating proteins [19-21]. Some of the research studies have confirmed that these proteins that show antimicrobial activity may be employed to generate pathogen resistance in transgenic strains [17,22].

Identification and characterization of proteins is an essential step to understand the key roles of proteins in the cell. In recent times, proteomic analysis has emerged as a successful technology to identify and characterize the loop link proteins that will merge the gap between proteomics and pharmacology. In our study we adopted the gel electrophoresis technique to separate proteins by 2DE, followed by protein identification by mass spectrometry, which is a widely used approach in proteomics.

\section{Results and Discussion}

The protein extract after extracting in sodium acetate buffer, $\mathrm{pH}-6.5$, were purified by dialysis, and the same extract was concentrated and subjected for antibacterial testing against four standard pathogenic bacterial strains found to cause foodborne illness and spoilage of food and herbal drugs. The bacterial strains used in the study were Escherichia Coli (E. coli), Pseudomonas aeruginosa (P. aeruginosa), Staphylococcus aureus (S. aureus), and Proteus vulgaris (P. vulgaris), and compared with the standard antibiotics ciprofloxacin $(25 \mathrm{mcg} / \mathrm{mL})$ and chloramphenicol $(100 \mathrm{mcg} / \mathrm{mL})$.

\subsection{Comparison of Protein Concentration Extracted in Different Buffers after Dialysis}

The result of the study shown in Table 1 reveals that different buffers and $\mathrm{pH}$ vary in the concentration of protein extracts. Seeds of Foeniculum vulgare Mill., showed low concentration of protein, at $80 \mu \mathrm{g} / \mathrm{mL}$, when extracted in sodium phosphate citrate buffer (pH-7.2) and CTAB buffer ( $\mathrm{pH}$ 6.0), and exhibited the highest concentration of protein, at $140 \mu \mathrm{g} / \mathrm{mL}$, with sodium acetate buffer (pH-6.5).

Table 1. Protein concentration ( $\mu \mathrm{g} / \mathrm{mL})$ in Foeniculum vulgare Mill. extract by different buffers after dialysis.

\begin{tabular}{ccccc}
\hline S. No & Plant & $\begin{array}{c}\text { Sodium } \\
\text { Phosphate Citrate } \\
\text { Buffer }(\mathrm{pH}-7.2) \\
(\mu \mathrm{g} / \mathrm{mL})\end{array}$ & $\begin{array}{c}\text { CTAB Buffer } \\
(\mathrm{pH}-6.0) \\
(\mu \mathrm{g} / \mathrm{mL})\end{array}$ & $\begin{array}{c}\text { Sodium Acetate } \\
\text { Buffer (pH-6.5) } \\
(\mu \mathrm{g} / \mathrm{mL})\end{array}$ \\
\hline 1. & Foeniculum vulgare Mill. & 80 & 80 & 140 \\
\hline
\end{tabular}




\subsection{Antibacterial Activity of Sodium Acetate Buffer pH-6.0 Extracts after Dialysis}

Antibacterial activity results shown in Table 2 and Figure 1 were obtained from sodium phosphate citrate buffer and CTAB buffer extracts from Foeniculum vulgare Mill. (S1) were found to exhibit nil activity on all of the bacterial strains used, so this plant's seeds were again extracted in sodium acetate buffer, $\mathrm{pH}-6.5$, to obtain a sensitivity pattern on the bacterial strains. Pseudomonas aeruginosa exhibited very good sensitivity when compared with the other bacterial strains with a diameter of the zone of inhibition $12.5 \mathrm{~mm}$, whereas Staphylococcus aureus and Proteus vulgaris showed similar zones of inhibition of $12 \mathrm{~mm}$. E. coli, Pseudomonas aeruginosa, and Proteus vulgaris revealed good zone of inhibition patterns of $11 \mathrm{~mm}, 12.5 \mathrm{~mm}$, and $12 \mathrm{~mm}$, when compared with the standard antibiotic Chloramphenicol $(25 \mathrm{mcg} / \mathrm{mL})$, which is only $8 \mathrm{~mm}$.

Table 2. Diameter of the zone of inhibition of sodium acetate buffer, $\mathrm{pH}-6.5$, extracts after dialysis.

\begin{tabular}{cccc}
\hline S. No & S1 & Chl (25 $\mathbf{~ c g} / \mathbf{m L})$ & Cipro (100 $\mathbf{~ c g / m L ) ~}$ \\
\hline S. aureus & 12 & 21 & 16 \\
E. coli & 11 & 8 & 14 \\
P. aeruginosa & 12.5 & 8 & 12 \\
P. vulgaris & 12 & 8 & 14 \\
\hline
\end{tabular}

(S1) Foeniculum vulgare Mill., (Chl) Chloramphenicol and (Cipro) Ciprofloxacin. Staphylococcus aureus (S. aureus), Escherichia coli (E. coli), Pseudomonas aeruginosa (P. aeruginosa), and Proteus vulgaris (P. vulgaris).
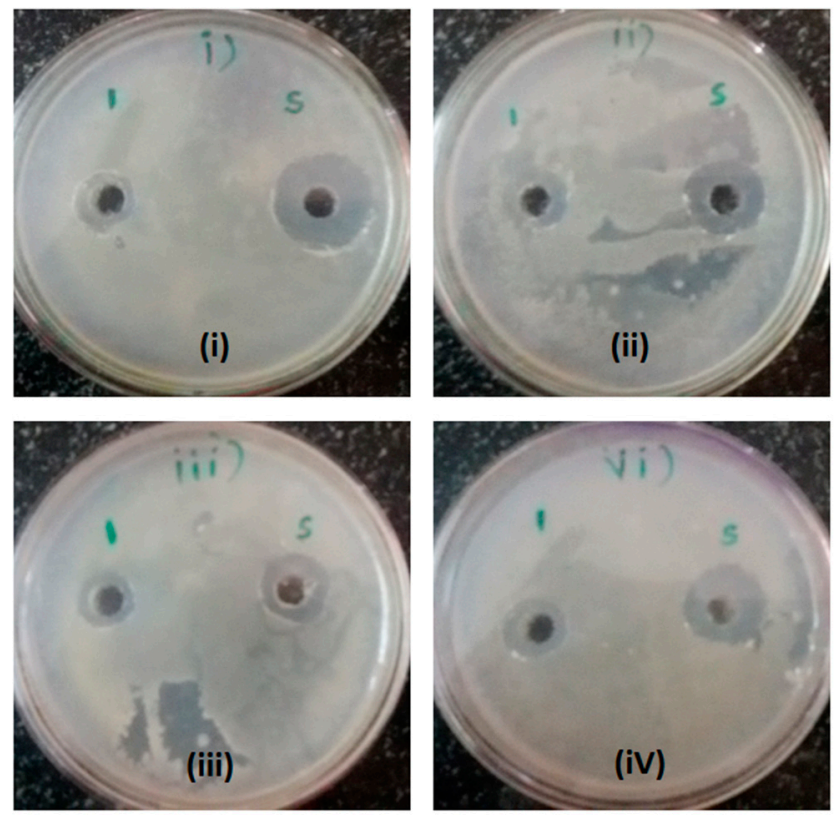

Figure 1. The photograph shows the antimicrobial activity of Foeniculum vulgare extracted in sodium acetate buffer at a $\mathrm{pH}$ of 6.5 after dialysis. In this figure, ' 1 ' indicates protein from Foeniculum vulgare and 'S' indicates standard antibiotic-Ciprofloxacin $(100 \mathrm{mcg} / \mathrm{mL})$. (i) S. aureus; (ii) E. coli; (iii) P. aeruginosa; and (iv) P. vulgaris.

\subsection{Protein Concentration of Ion Exchange Chromatography Elutes}

The crude protein extracts from Foeniculum vulgare Mill. extracted in sodium acetate buffer at a $\mathrm{pH}$ of 6.5 after dialysis were further purified using the DEAE-ion exchange chromatography technique to isolate and characterize the antibacterial proteins present in the extract. The crude protein extract after dialysis was subjected to ion exchange chromatography, four elutes were obtained, and the concentration was found using the Lowry method. The protein concentration was found in ranges 
from $100-120 \mathrm{mcg} / \mathrm{mL}$, the highest concentration was seen in elute 1 and 2 with $120 \mathrm{mcg} / \mathrm{mL}$, and the least was found in elute 4 , with $100 \mathrm{mcg} / \mathrm{mL}$, results shown in the Table 3.

Table 3. Comparison of the protein concentration $(\mathrm{mcg} / \mathrm{mL})$ after ion-exchange chromatography.

\begin{tabular}{ccccc}
\hline S. No & Elute 1 & Elute 2 & Elute 3 & Elute 4 \\
\hline Foeniculum vulgare Mill. & 120 & 120 & 110 & 100 \\
\hline
\end{tabular}

\subsection{Antibacterial Activity}

The results of Foeniculum vulgare elutes obtained after ion exchange chromatography were tested for antibacterial activity as shown in Table 4 and Figure 2. Elute 3 shows the highest antibacterial activity on $P$. aeruginosa with a diameter of the zone of inhibition of $16 \mathrm{~mm}$ and an $\mathrm{IC}_{50}$ value of $25.02 \mathrm{mcg} / \mathrm{mL}$, when compared with the standard antibiotic Chloramphenicol at $100 \mathrm{mcg} / \mathrm{mL}$ which is only $12 \mathrm{~mm}$ and has an $\mathrm{IC}_{50}$ value of $14.634 \mathrm{mcg} / \mathrm{mL}$. Elute 2 shows a good zone of inhibition on Proteus vulgaris with a diameter of the zone of inhibition of $13 \mathrm{~mm}$ and an $\mathrm{IC}_{50}$ value of $57.83 \mathrm{mcg} / \mathrm{mL}$, and the lowest zone of inhibition was seen on P. aeruginosa with a zone of inhibition of $4 \mathrm{~mm}$ and an $\mathrm{IC}_{50}$ value of $68.33 \mathrm{mcg} / \mathrm{mL}$. S. aureus was found to shown good sensitivity toward elute 4 with a diameter of the zone of inhibition of $12 \mathrm{~mm}$ and an $\mathrm{IC}_{50}$ value of $20.8 \mathrm{mcg} / \mathrm{m}$ ) and, with elute 1 , a diameter of the zone of inhibition of $10 \mathrm{~mm}$ and an $\mathrm{IC}_{50}$ value $27.64 \mathrm{mcg} / \mathrm{mL}$. E. coli exhibited good sensitivity towards elute 1 with a zone of inhibition at $13 \mathrm{~mm}$ and $\mathrm{IC}_{50}$ value of $67.56 \mathrm{mcg} / \mathrm{mL}$.

Table 4. Antibacterial activity of ion exchange chromatography elutes from Foeniculum vulgare, diameter of the zone of inhibition $(\mathrm{mm})$, and $\mathrm{IC}_{50}$ values $(\mathrm{mcg} / \mathrm{mL})$.

\begin{tabular}{ccccccccccc}
\hline & \multicolumn{2}{c}{ Elute $\mathbf{1}$} & \multicolumn{2}{c}{ Elute 2 } & \multicolumn{2}{c}{ Elute 3 } & \multicolumn{2}{c}{ Elute 4 } & \multicolumn{2}{c}{ Cipro (100 mcg) } \\
\cline { 2 - 11 } S. No & ZOI & $\begin{array}{c}\text { IC }_{\mathbf{5 0}} \\
\text { Value }\end{array}$ & ZOI & $\begin{array}{c}\text { IC }_{\mathbf{5 0}} \\
\text { Value }\end{array}$ & ZOI & $\begin{array}{c}\text { IC }_{\mathbf{5 0}} \\
\text { Value }\end{array}$ & ZOI & $\begin{array}{c}\text { IC }_{\mathbf{5 0}} \\
\text { Value }\end{array}$ & $\begin{array}{c}\text { ZOI } \\
\text { IC }_{\mathbf{5 0}} \\
\text { Value }\end{array}$ \\
\hline S. aureus & 10 & 27.64 & 8 & 25.91 & 8 & 21.27 & 12 & 20.8 & 16 & 160.529 \\
E. coli & 13 & 67.56 & 12 & 64.12 & 6 & 60.52 & 8 & 41.06 & 14 & 92.489 \\
P. aeruginosa & 5 & 28.01 & 4 & 68.33 & 16 & 25.02 & 10 & 26.67 & 12 & 144.634 \\
P. vulgaris & 12 & 59.68 & 13 & 57.83 & 6 & 41.25 & 7 & 35.67 & 14 & 72.685 \\
\hline
\end{tabular}
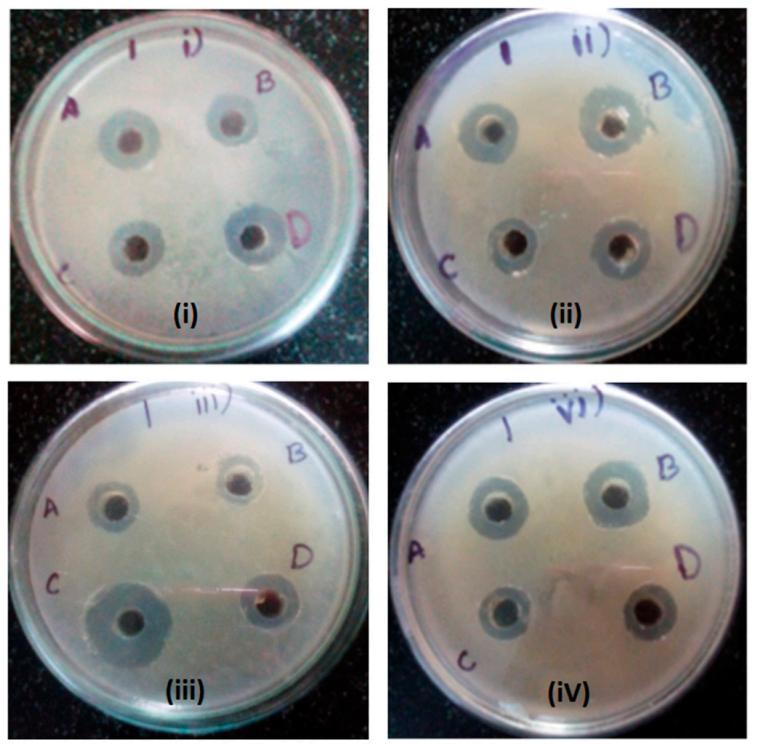

Figure 2. The diameter of the zone of inhibition of ion exchange chromatography elutes from Foeniculum vulgare. S. aureus (i), E. coli (ii), P. aeruginosa (iii), and P. vulgaris (iv). A, B, C, and D represent elutes $1,2,3$, and 4 , respectively. 
The analysis was performed using SAS for Windows version 9.2 (SAS Institute Inc., Cary, NC, USA). One-way ANOVA was used to compare the $\mathrm{IC}_{50}$ of different elutes on four bacterial strains used in the study. Among the tested strains, S. aureus and P. vulgaris showed the highest significant inhibition in comparison to standard cipro $(p=0.02)$ whereas there is no significance observed in the $\mathrm{IC}_{50}$ in E. coli and P. aeruginosa compared to standard cipro, results shown in Table 5.

Table 5. ANOVA analysis of $\mathrm{IC}_{50}$ values compared to different strains.

\begin{tabular}{cccccccc}
\hline \multirow{2}{*}{$\begin{array}{c}\text { Bacterial } \\
\text { Strains }\end{array}$} & Elute $\mathbf{1}$ & Elute $\mathbf{2}$ & Elute $\mathbf{3}$ & Elute $\mathbf{4}$ & Cipro & \multirow{2}{*}{$\boldsymbol{t}$ Value } & $\boldsymbol{p}$-Value * \\
\cline { 2 - 6 } & $\mathbf{I C}_{\mathbf{5 0}}$ & $\mathbf{I C}_{\mathbf{5 0}}$ & $\mathbf{I C}_{\mathbf{5 0}}$ & $\mathbf{I C}_{\mathbf{5 0}}$ & $\mathbf{I C}_{\mathbf{5 0}}$ & & \\
\hline S. aureus & 27.64 & 25.91 & 21.27 & 20.8 & 160.529 & 6.2 & 0.025 \\
E. coli & 67.56 & 64.12 & 60.52 & 41.06 & 92.489 & 2.39 & 0.139 \\
P. aeruginosa & 28.01 & 68.33 & 25.02 & 26.67 & 144.634 & 3.4 & 0.077 \\
P. vulgaris & 59.68 & 57.83 & 41.25 & 35.67 & 72.685 & 6.5 & 0.023 \\
\hline
\end{tabular}

* One-way ANOVA test. $p<0.05$.

\subsection{2-D Gel Electrophoresis Results}

The purified proteins from Foeniculum vulgare seeds after anion exchange chromatography were subjected to 2-DE. Out of four elutes obtained from anion exchange chromatography, only elute 2 was used for 2-DE analysis. The elute 2 protein sample extracted from Foeniculum vulgare seeds was analyzed to investigate the proteins present in the sample based on the molecular weight, using HP Scanjet G4010 proteomic techniques. The analysis of 2D gel of Foeniculum vulgare showed reproducible protein spots, most of which were distributed near the center of the gels, between pI values 5-8 and molecular weight of $34.4 \mathrm{kDa}$ and $48 \mathrm{kDa}$ (Figure 3).

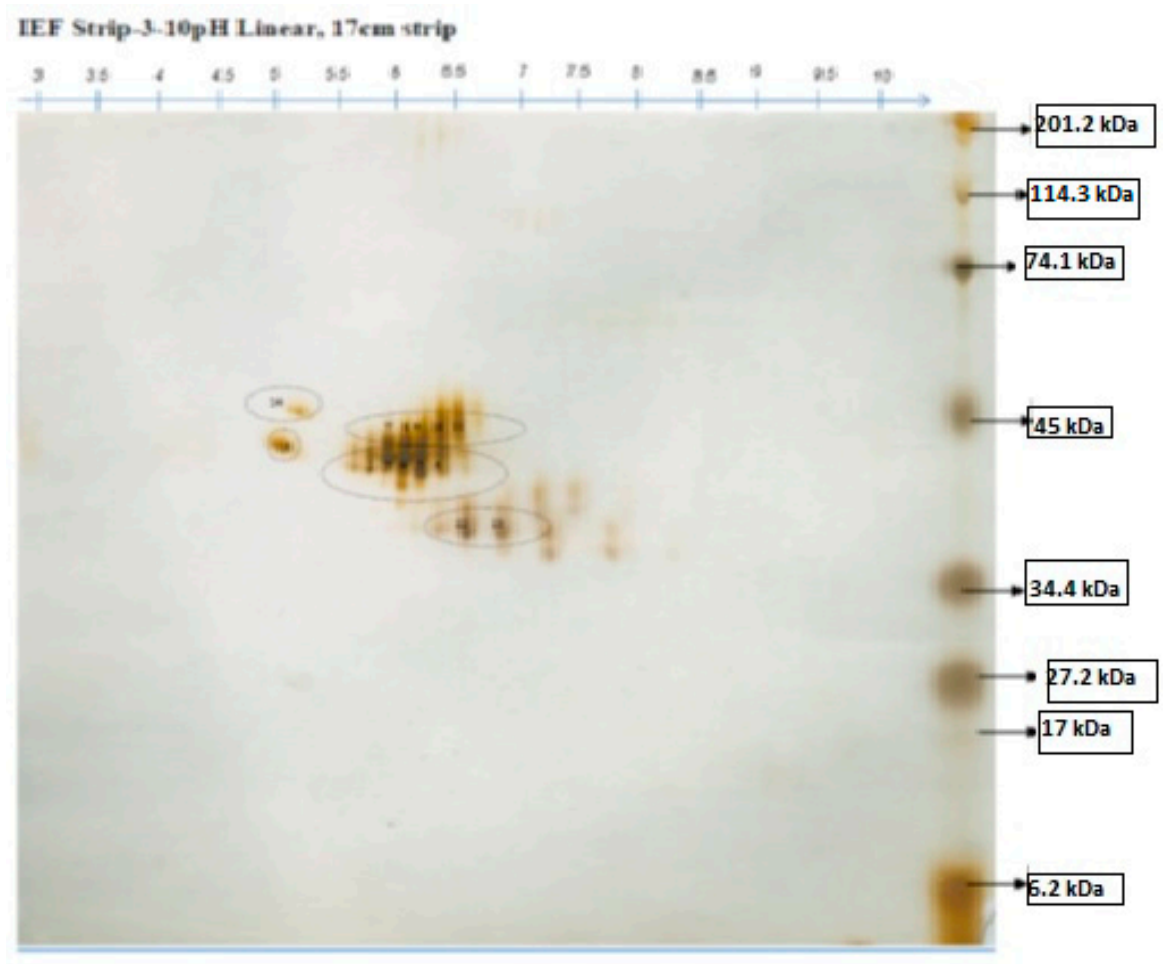

Figure 3. The protein spots of elute 2 obtained after ion exchange chromatography. Marker used: Biorad Prestained SDS-PAGE Standard, Broad Range. IEF strip pH 3-10 linear, $17 \mathrm{~cm}$.

Antibiotic resistance is one the most dangerous global problems today, which makes antimicrobial proteins/peptides the agents of a substitute for cures of pathogenic diseases [23]. In this study, we 
have extracted $3 \mathrm{kDa}$ antimicrobial peptides from Foeniculum vulgare Mill. seeds using buffers and the specific proteins of interest were purified with a dialysis technique using $3 \mathrm{kDa}$ dialysis tubing. Conversely, further separation was done using DEAE-ion exchange chromatography and four elutes were subjected to antimicrobial activity, out of which elute 2 has promising results, which was then characterized by using 2D gel electrophoresis. Much expected optimistic results were obtained against tested pathogenic bacteria, where they exhibited antibacterial activity in comparison to the standard cipro $(100 \mathrm{mcg})$. Past studies have demonstrated that asymptomatic bacteriuria posed more serious hazards in pregnant women [24], so bacterial resistance is inciting a resurgence in research of the antimicrobial activities of herbs against resistant strains $[25,26]$.

In the present research work on anion exchange resin diethyl amino ethyl cellulose (DEAE) was used, which is positively-charged to exchange negatively-charged protein. DEAE-ion exchange chromatography is one of the promising techniques used to separate proteins based on their surface ionic charge using resins that are altered with either negatively-charged or positively-charged biochemical groups [27]. As in this study, anion exchange resin DEAE is being used, as proteins purified by ion exchange chromatography may contain a negative charge.

Proteomics is a handy technique used in the characterization of various proteins [28]. Additionally, 2-DE polyacrylamide gel electrophoresis is a potent technique and, as such, can be adopted to separate and determine protein mixtures of thousands of specific components [29], is based on the gel size, is capable of determining more than 5000 proteins at once, and can detect with less than $1 \mathrm{mg}$ of sample per spot. In our research work, 2-D PAGE is used for the characterization of anionic proteins from elute 2 of the ion-exchange chromatography sample of Foeniculum vulgare seed extract, and most of the protein spots were found to be between $\mathrm{pI}$ values $5-8$ and molecular weights of $34.4 \mathrm{kDa}$ and $48 \mathrm{kDa}$ on the 2D gel, which was found to be higher in molecular weight and possess antibacterial activity from being tested on the four bacterial strains. Previous study identified napins, a class of proteins from $2 \mathrm{~S}$ albumin, which were isolated from plants and that can be easily extracted from seeds [30] which are composed of $10 \mathrm{kDa}$ and $4.5 \mathrm{kDa}$ subunits [31]. Furthermore the present study has provided more evidence that the high mass protein isolated from the Gram-negative plant pathogen, and also more researchers' stated literature reports on carotovoricin [32] and colicins [33-35], authenticating our present research study.

\section{Experimental Section}

\subsection{Materials}

The Foeniculum vulgare Mill. seeds were procured from a local market in Riyadh, Saudi Arabia. Before adopting the protocol, the plant seeds were identified by Dr. Ali S. Alqahtani, Pharmacognosy Department, King Saud University, Riyadh, Saudi Arabia. Ethical approval was obtained from the research ethics committee (CAMS-153-36/37) from the college of Applied Medical Sciences, King Saud University, Riyadh, Saudi Arabia.

\subsection{Preparation of Plant Seeds Extract}

The Foeniculum vulgare Mill. seeds were cleaned using sterile water to remove any debris left over on the seeds and dried in a biological safety cabin to maintain the sterile condition. Later, fine powder was prepared from the seeds under aseptic conditions and the extract was soaked in sodium phosphate buffer (pH-6.5) at $30{ }^{\circ} \mathrm{C}$ and left for overnight incubation. The next day, extracts were filtered with Whattmann filter paper No. 1 and subjected to $80 \%$ ammonium sulfate saturation. The collected saturated material was then separated by dialysis using a $3 \mathrm{kDa}$ cutoff dialysis tubing (Sigma Aldrich, St. Louis, MO, USA) and the protein' concentration was further estimated by spectroscopic analysis at a wavelength of $280 \mathrm{~nm}$. 


\subsection{DEAE-Ion Exchange Chromatography}

The chromatography column was prepared using a DEAE cellulose bed of $1 \mathrm{~cm}$ thickness, washed with ethanol before use, $20 \mathrm{mM}$ Tris-Hcl for the $250 \mathrm{~mL}$ required volume was prepared, and $\mathrm{pH}$ was attuned to 8.5 using $\mathrm{NaOH}$. Bed preparation: counter ions (salt gradient) of $40 \mathrm{~mL}$ of $25 \mathrm{mM} \mathrm{NaCl}$ in $50 \mathrm{mM}$ tris (pH-7.2) and 0.3\% of DEAE were applied to the column. The elutes were run for $4 \mathrm{~h}$ and $2 \mathrm{~mL}$ was collected. Each column used a flash chromatography column from Sigma Aldrich, St. Louis, (MO, USA), and the eluting buffer was sodium phosphate citrate buffer (pH-7.2). Elute preparation: four elutes were prepared in test tubes for each dialyzed sample. After dialysis, the samples were poured into the column without disturbing the bed, and left for $20 \mathrm{~min}$ to settle. The first eluting buffer, i.e., sodium phosphate citrate buffer (pH-7.2), was loaded into the column and was used to elute the sample. Thed column was allowed to settle for $15-20 \mathrm{~min}$. The flow rate is adjusted to $1 \mathrm{~mL} / \mathrm{min}$ and the elute was collected in test tubes at the bottom.

\subsection{Bacterial Strains}

Bacterial strains used for the study were E. coli, P. aeruginosa S. aureus, and P. vulgaris, and were obtained from department of laboratory sciences, College of Applied Medical Sciences, Riyadh, Saudi Arabia.

\subsection{Culture Medium and Inoculum Preparation}

Antibacterial activity of this crude extract was tested against these four strains in Hi-media. Culture slants were prepared by taking a loop full of pure culture and dispensing into $10 \mathrm{~mL}$ nutrient broth from four strains in a sterilized laminar flow and incubated for two days in the incubator. The final concentration of each active culture was maintain at $108 \mathrm{cfu} / \mathrm{mL}$.

\subsection{Agar Well Diffusion Assay}

The antibacterial activity of the crude protein extracts was determined by agar well diffusion assay [36]. Pure cultures were dispersed on agar plates using sterile cotton swabs. Next, using a sterile borer, wells were created on the agar plates. Crude protein extracts $(100 \mu \mathrm{L})$ filled the wells, with antibiotic and buffer as negative controls, and incubated for a day in an incubator. All of the plates were conducted in triplicate to ensure accurate results [37] and the zone of inhibition was measured in millimeters.

\subsection{Determination of the Minimal Inhibitory Concentration (MIC)}

The protein extracts of different plant seeds were tested for antibacterial activity against four strains by the micro-dilution method [38], with some alterations and suggestions by NCCLS (NCCLS, 2001). Different concentrations of extracts were loaded in $96-$ well plates to check the antibacterial activity of the extracted proteins. The suspension of culture with $10^{8} \mathrm{cfu} / \mathrm{mL}$ concentration added to each well and made a final volume to $200 \mu \mathrm{L}$ by adding LB broth. Ten microliters of MTT $(5 \mathrm{mg} / \mathrm{mL})$ was added to all of the wells after incubation at $\pm 4{ }^{\circ} \mathrm{C}$ for $18 \mathrm{~h}$ and the readings were taken at $530 \mathrm{~nm}$ using an ELISA reader (Tecan, Männedorf, Switzerland). The minimum concentration of protein that showed total inhibition was considered as its MIC minimum zone of inhibition. As control experiments, Chloramphenicol (25 mcg) and Ciprofloxacin (100 mcg) were taken as positive controls, and sterile broth as the negative control.

\subsection{Statistical Analysis}

The inhibition concentration at $50 \%$ inhibition $\left(\mathrm{IC}_{50}\right)$ was the parameter used to compare the antibacterial activity. A lower $\mathrm{IC}_{50}$ means better antibacterial activity. All of the tests were performed in triplicate and the results were expressed as the mean \pm standard deviation. The percent of inhibition of 
antibacterial activity of the protein was calculated based on: $\%$ Inhibition $=($ A control $-\mathrm{A}$ sample $) / \mathrm{A}$ control $\times 100$.

\subsection{Two-Dimensional Electrophoresis}

Two-dimensional (2-D) electrophoresis, one the most important tool in proteomics, was performed in accordance with the method reported in [29]. The sample was dissolved in $120 \mu \mathrm{L}$ of rehydration buffer, loaded onto the $17 \mathrm{~cm}$ IEF strip 3-10 pH Liner, (Biorad, Hercules, California, CA, USA), and retained for iso-electric focusing. Next, the strips were equilibrated in equilibrium buffer after finishing the IEF run and the second dimension was run on $12 \%$ SDS PAGE.

\section{Conclusions}

Over a long period of time, Foeniculum vulgare seeds have shown promise in traditional medicine for the treatment of a wide range of diseases. From our results, 14 spots from the $2 \mathrm{D}$ gel were eluted and further subjected to mass spectrometry studies, undergoing more proteomic analyses and the isolation of small peptides from Foeniculum vulgare. Many studies have reported that this plant has numerous in vivo and in vitro pharmacological assets that can be used in various aspects of prognosis. Based on the findings of the wide usage in treatment of various ailments and day-to-day life, Foeniculum vulgare seeds were used in the present research and have established the promising antibacterial effects of these seeds, which require further proteomic research to authenticate the role of anticipated proteins.

Acknowledgments: Authors would like to thank Twasol Research Excellence Program (TRE Program), King Saud University, Riyadh, Saudi Arabia for support.

Author Contributions: Ayesha Mateen and Rabbani Syed, designed the project; Abdullah A. Alyousef, and Raid Al Akeel were involved in the identification, extraction, and characterization of antimicrobial peptide; Mohammed Rafi Shaik carried out the ion exchange chromatography; Ayesha Mateen completed the characterization by 2D gel electrophoresis; Rabbani Syed and Ayesha Mateen was involved in isolating the antimicrobial peptide and testing against reference strains, Mohammed Rafi Shaik helped to draft the manuscript. All authors read and approved the final manuscript.

Conflicts of Interest: The authors declare no conflict of interest.

\section{References}

1. Stintzi, A.; Heitz, T.; Prasad, V.; Wiedemann-Merdinoglu, S.; Kauffmann, S.; Geoffroy, P.; Legrand, M.; Fritig, B. Plant 'pathogenesis-related' proteins and their role in defense against pathogens. Biochimie 1993, 75, 687-706. [CrossRef]

2. Sinha, M.; Singh, R.P.; Kushwaha, G.S.; Iqbal, N.; Singh, A.; Kaushik, S.; Kaur, P.; Sharma, S.; Singh, T.P. Current overview of allergens of plant pathogenesis related protein families. Sci. World J. 2014, 2014, 543195. [CrossRef] [PubMed]

3. Egorov, T.A.; Odintsova, T.I.; Pukhalsky, V.A.; Grishin, E.V. Diversity of wheat anti-microbial peptides. Peptides 2005, 26, 2064-2073. [CrossRef] [PubMed]

4. Reddy, K.; Yedery, R.; Aranha, C. Antimicrobial peptides: Premises and promises. Int. J. Antimicrob. Agents 2004, 24, 536-547. [CrossRef] [PubMed]

5. Montalbán-López, M.; Sánchez-Hidalgo, M.; Cebrián, R.; Maqueda, M. Discovering the bacterial circular proteins: Bacteriocins, cyanobactins, and pilins. J. Biol. Chem. 2012, 287, 27007-27013. [CrossRef] [PubMed]

6. Tam, J.P.; Wong, C.T. Chemical synthesis of circular proteins. J. Biol. Chem. 2012, 287, 27020-27025. [CrossRef] [PubMed]

7. Hammami, R.; Hamida, J.B.; Vergoten, G.; Fliss, I. Phytamp: A database dedicated to antimicrobial plant peptides. Nucleic Acids Res. 2009, 37, D963-D968. [CrossRef] [PubMed]

8. Badgujar, S.B.; Patel, V.V.; Bandivdekar, A.H. Foeniculum vulgare Mill.: A review of its botany, phytochemistry, pharmacology, contemporary application, and toxicology. BioMed Res. Int. 2014, 2014, 842674. [CrossRef] [PubMed]

9. Mohsenzadeh, M. Evaluation of antibacterial activity of selected Iranian essential oils against Staphylococcus aureus and Escherichia coli in nutrient broth medium. Pak. J. Biol. Sci. 2007, 10, 3693-3697. [PubMed] 
10. Leah, R.; Tommerup, H.; Svendsen, I.; Mundy, J. Biochemical and molecular characterization of three barley seed proteins with antifungal properties. J. Biol. Chem. 1991, 266, 1564-1573. [PubMed]

11. Melchers, L.S.; Groot-de, M.A.; Knaap, J.A.; Ponstein, A.S.; Sela-Buurlage, M.B.; Bol, J.F.; Cornelissen, B.J.; Elzen, P.J.; Linthorst, H.J. A new class of tobacco chitinases homologous to bacterial exo-chitinases displays antifungal activity. Plant J. 1994, 5, 469-480. [CrossRef] [PubMed]

12. Broekaert, W.F.; Terras, F.; Cammue, B.; Osborn, R.W. Plant defensins: Novel antimicrobial peptides as components of the host defense system. Plant Physiol. 1995, 108, 1353-1358. [CrossRef] [PubMed]

13. Thomma, B.P.; Cammue, B.P.; Thevissen, K. Plant defensins. Planta 2002, 216, 193-202. [CrossRef] [PubMed]

14. Florack, D.; Stiekema, W. Thionins: Properties, possible biological roles and mechanisms of action. Plant Mol. Biol. 1994, 26, 25-37. [CrossRef] [PubMed]

15. Cammue, B.P.A.; Thevissen, K.; Hendriks, M.; Eggermont, K.; Goderis, I.J.; Proost, P.; Van Damme, J.; Osborn, R.W.; Guerbette, F.; Kader, J.-C. A potent antimicrobial protein from onion seeds showing sequence homology to plant lipid transfer proteins. Plant Physiol. 1995, 109, 445-455. [CrossRef] [PubMed]

16. Cheng, C.-S.; Samuel, D.; Liu, Y.-J.; Shyu, J.-C.; Lai, S.-M.; Lin, K.-F.; Lyu, P.-C. Binding mechanism of nonspecific lipid transfer proteins and their role in plant defense. Biochemistry 2004, 43, 13628-13636. [CrossRef] [PubMed]

17. Agizzio, A.P.; Carvalho, A.O.; Suzanna de Fátima, F.R.; Machado, O.L.; Alves, E.W.; Okorokov, L.A.; Samarão, S.S.; Bloch, C.; Prates, M.V.; Gomes, V.M. A $2 S$ albumin-homologous protein from passion fruit seeds inhibits the fungal growth and acidification of the medium by Fusarium oxysporum. Arch. Biochem. Biophys. 2003, 416, 188-195. [CrossRef]

18. Terras, F.; Schoofs, H.; De Bolle, M.; Van Leuven, F.; Rees, S.B.; Vanderleyden, J.; Cammue, B.; Broekaert, W.F. Analysis of two novel classes of plant antifungal proteins from radish (Raphanus satious L.) seeds. J. Biol. Chem. 1992, 267, 15301-15309. [PubMed]

19. Barbieri, L.; Battelli, M.G.; Stirpe, F. Ribosome-inactivating proteins from plants. BBA-Biomembranes 1993, 1154, 237-282. [CrossRef]

20. Dong, T.; Ng, T.; Yeung, H.; Wong, R. Isolation and characterization of a novel ribosome-inactivating protein, $\beta$-kirilowin, from the seeds of Trichosanthes kirilowii. Biochem. Biophys. Res. Commun. 1994, 199, 387-393. [CrossRef] [PubMed]

21. Park, S.-W.; Vepachedu, R.; Sharma, N.; Vivanco, J.M. Ribosome-inactivating proteins in plant biology. Planta 2004, 219, 1093-1096. [CrossRef] [PubMed]

22. Jach, G.; Görnhardt, B.; Mundy, J.; Logemann, J.; Pinsdorf, E.; Leah, R.; Schell, J.; Maas, C. Enhanced quantitative resistance against fungal disease by combinatorial expression of different barley antifungal proteins in transgenic tobacco. Plant J. 1995, 8, 97-109. [CrossRef] [PubMed]

23. Hoda, H.; Elmi, F.; Elmi, M.M. Electrophoretic pattern and antibacterial activity of proteins from vicia faba seed extract. Int. J. Mol. Cell. Med. 2013, 2, 46-49. [PubMed]

24. Imade, P.E.; Izekor, P.E.; Eghafona, N.O.; Enabulele, O.I.; Ophori, E. Asymptomatic bacteriuria among pregnant women. N. Am. J. Med. Sci. 2010, 2, 263-266. [PubMed]

25. Alviano, D.; Alviano, C. Plant extracts: Search for new alternatives to treat microbial diseases. Curr. Pharm. Biotechnol. 2009, 10, 106-121. [CrossRef] [PubMed]

26. Hemaiswarya, S.; Kruthiventi, A.K.; Doble, M. Synergism between natural products and antibiotics against infectious diseases. Phytomedicine 2008, 15, 639-652. [CrossRef] [PubMed]

27. Cseke, L.; Podila, G. MADS-box genes in dioecious aspen II: A review of MADS-box genes from trees and their potential in forest biotechnology. Hysiol. Mol. Biol. Plants 2004, 10, 7-28.

28. Freed, J.K.; Smith, J.R.; Li, P.; Greene, A.S. Isolation of signal transduction complexes using biotin and crosslinking methodologies. Proteomics 2007, 7, 2371-2374. [CrossRef] [PubMed]

29. Görg, A.; Weiss, W.; Dunn, M.J. Current two-dimensional electrophoresis technology for proteomics. Proteomics 2004, 4, 3665-3685. [CrossRef] [PubMed]

30. Barciszewski, J.; Maciej, S.; Haertlé, T. Minireview: Analysis of rape seed napin structure and potential roles of the storage protein. J. Protein Chem. 2000, 19, 249-254. [CrossRef] [PubMed]

31. Gehrig, P.; Biemann, K. Assignment of the disulfide bonds in napin, a seed storage protein from Brassica napus, using matrix-assisted laser desorption ionization mass spectrometry. Pept. Res. 1995, 9, 308-314. 
32. Yamada, K.; Hirota, M.; Niimi, Y.; Nguyen, H.A.; Takahara, Y.; Kamio, Y.; Kaneko, J. Nucleotide sequences and organization of the genes for carotovoricin (Ctv) from Erwinia carotovora indicate that Ctv evolved from the same ancestor as Salmonella typhi prophage. Biosci. Biotechnol. Biochem. 2006, 70, 2236-2247. [CrossRef] [PubMed]

33. Feil, H.; Feil, W.S.; Chain, P.; Larimer, F.; DiBartolo, G.; Copeland, A.; Lykidis, A.; Trong, S.; Nolan, M.; Goltsman, E. Comparison of the complete genome sequences of Pseudomonas syringae pv. syringae B728a and pv. tomato DC3000. Proc. Natl. Acad. Sci. USA 2005, 102, 11064-11069. [CrossRef] [PubMed]

34. Chuang, D.-Y.; Chien, Y.-C.; Wu, H.-P. Cloning and expression of the Erwinia carotovora subsp. carotovora gene encoding the low-molecular-weight bacteriocin carocin S1. J. Bacteriol. 2007, 189, 620-626. [PubMed]

35. Ochiai, H.; Inoue, Y.; Takeya, M.; Sasaki, A. Genome sequence of Xanthomonas oryzae pv. oryzae suggests contribution of large numbers of effector genes and insertion sequences to its race diversity. Jpn. Agric. Res. Q. JARQ 2005, 39, 275-287.

36. Hawkey, P.; Lewis, D. Medical Bacteriology: A Practical Approach; OUP Oxford: Oxford, UK, 2003; Volume 265.

37. Camporese, A.; Balick, M.; Arvigo, R.; Esposito, R.; Morsellino, N.; De Simone, F.; Tubaro, A. Screening of anti-bacterial activity of medicinal plants from Belize (central America). J. Ethnopharmacol. 2003, 87, 103-107. [CrossRef]

38. Black, J.G. Microbiology: Principles and Explorations; John Wiley \& Sons: Hoboken, NJ, USA, 2008.

Sample Availability: Samples of the compounds are not available from the authors.

(C) 2017 by the authors. Licensee MDPI, Basel, Switzerland. This article is an open access article distributed under the terms and conditions of the Creative Commons Attribution (CC BY) license (http:/ / creativecommons.org/licenses/by/4.0/). 